\title{
YOUTH TRANSITIONS: FROM OFFENDING TO DESISTANCE
}

\author{
Dr. Monica Barry
}

\begin{abstract}
This article examines youth transitions and youth offending in tandem. It argues that the transition to adulthood is heavily implicated in the fact that most offending occurs in the youth phase. Drawing on a study of 20 male and 20 female persistent young offenders in Scotland, it explores young people's desire for integration with others in the transition phases - with their families in childhood, with their friends in youth and with the wider society in adulthood. During the youth phase, much of that integration comes from offending itself, whereas when more legitimate opportunities and sources of recognition are offered to them in early adulthood, desistance is more likely to occur.
\end{abstract}

\section{INTRODUCTION}

Children and young people have been set apart from adults by dint of their age and status rather than their capacities and competences (Archard, 1993; Franklin, 2002). There are special measures in place to protect them from harm (whether this be selfinflicted or imposed by others), they are herded into institutionalised educational establishments from the age of five purportedly to improve their life chances, and they can be denied access to opportunities afforded 'adults' in mainstream society until they are well into their twenties. They are the main focus of criminal enquiry and their 
behaviour is often seen as abnormal, rebellious or pathological rather than a manifestation of the power imbalances inherent in society.

The fact that offending behaviour is primarily the preserve of youth has challenged criminologists for the best part of a century to date and will no doubt continue to do so. Burt's (1925) medical-psychological study initiated a wave of positivist research that made young people 'the hapless population upon which much of the emphasis of "scientific criminology" and "administrative criminology" was to come to rest' (quoted in Brown: 1998: 21). This article suggests that young people strive towards conventionality and integration within society (MacDonald, 1997; Williamson, 1997) rather than rebellion against it. The fact is that the majority of young people who are marginalised or otherwise disadvantaged, within the labour market as elsewhere, do not rebel against their predicament and indeed aspire towards mainstream goals (MacDonald, 1997; Williamson, 1997; Wyn and White, 1997):

The response of the unemployed to the aggravation of labour market disadvantage lies not in the development of some highly distinctive subculture, but in the reinforcement of more conventional working-class beliefs (Gallie, 1994, p. 756, quoted in MacDonald, 1997).

Young people also adopt diverse pathways in the transition to adulthood but are restricted by structural constraints, notably in relation to their legal status as young adults as well as their opportunities for further education and employment. The importance of social inequalities and social institutions in determining or undermining youth transitions is becoming increasingly apparent. Many young 
people are excluded from higher education (through a lack of qualifications or financial support), from employment opportunities and from housing.

\section{YOUTH TRANSITIONS}

The advent in the UK of Thatcherism in the late 1970s marked a turning point not only for young people who became increasingly marginalised within a contracted youth labour market, but also for sociologists of youth who had hitherto concentrated their attention on youth subcultures at the expense of structural constraints on youth transitions (MacDonald et al, 2001). In an attempt to redress the balance in favour of misguided policy rather than misguided youth, transitions research in the 1980s and early 1990s focused more on structural constraints than on individual choice. However, this early transitions research has been increasingly criticised for being overly deterministic and throwing the proverbial baby out with the bath water in its often navel-gazing and myopic attitude to the structure versus agency debate. As Miles (2000) argues:

The tendency... to adopt a structural perspective on transitions has been counter-productive, primarily because of its failure to prioritize the actual views, experiences, interests and perspectives of young people as they see them, in favour of bland discussions, most commonly of trends in employment and education patterns (quoted in MacDonald et al, 2001: 4).

Traditionally, transitions research has portrayed a linear, psychosocial movement towards conventional goals. The main transitional pathways or 'careers' identified by 
sociologists in the 1980s and early 1990s have been summarised by Coles (1995) as follows:

- the transition from full-time education and training to a full-time job in the labour market (the school-to-work transition);

- the transition from family of origin (mainly the biological family) to family of destination (the domestic transition);

- the transition from residence with parents (or surrogate parents) to living away from them (the housing transition) (Coles, 1995: 8).

Prior to this increasing sociological interest in youth transitions, anthropologists had been examining the experiences of adolescents in small-scale societies and the 'rites of passage' that they progress through in preparation for adulthood. Whilst the term 'youth' was not seen as a middle phase between childhood and adulthood in such anthropological studies, Van Gennep (1960, cited in Turner, 1967) nevertheless identified three elements in the transition from childhood to adulthood in terms of 'rites of passage'. These are:

separation - 'symbolic behaviour signifying the detachment of the individual or group either from an earlier fixed point in the social structure or a set of cultural conditions; 
margin - "during the intervening "liminal" period, the characteristics of the ritual subject (the "passenger") are ambiguous; he passes through a cultural realm that has few or none of the attributes of the past or coming state;

aggregation - 'the passage is consummated. The ritual subject... is in a stable state once more and, by virtue of this, has rights and obligations vis-à-vis others of a clearly defined and “structural” type' (ibid: 94-95).

Turner (1969) describes individuals within the liminal phase as: 'persons or principles that (1) fall in the interstices of social structure, (2) are on its margins, or (3) occupy its lowest rungs' (ibid: 125). The elements of transition described by Turner, van Gennep and Coles, amongst others, are predominantly structurally defined and determined, whereas one further element less often cited in the youth transition literature is that of the transition from dependence to independence (Jones, 1996). This more individualised description of the transition phase allows young people's own narratives to come to the fore, and it is these narratives that have recently made academics question the linear approach to transitions which had hitherto been the norm. Stephen and Squires (2003), for example, argue that young people's transitions in late modernity are neither linear nor predictable but are fragmented, prolonged and cyclical. Equally, young people are increasingly seen as being proactive in defining, negotiating and making sense of their own transitions. Many recent accounts of young people's experience of youth transitions (inter alia, Barry, 2001; Holland et al, 2007; Thomson et al, 2004) suggest that their narratives and transitional experiences are guided as much by personal agency and responsibility as they are by structural factors. Indeed, according to Beck (1992), the certainties associated with industrial society have been eroded by a new age of modernity consisting of uncertain risks and 
opportunities, resulting in what he terms 'individualization'. This suggests that young people now have to resolve their own problems, overcome structural constraints and ‘individualize' their own life projects (Cote, 2002).

This fragmentation of past stability has resulted, in the last decade or so, in the transition research pendulum swinging away from structuralism and back towards a 'new freedom' of individualised lifestyles and reflexive construction of one's own biography (Holland et al., 1999). Whilst the concept of individualisation describes both structure and agency, the individual is nevertheless at the centre (albeit structurally defined), and factors such as class, gender and social networks are peripheral. Furlong and Cartmel (2006), however, warn against an over-emphasis on individualisation at the expense of social and structural change, suggesting it would be an 'epistemological fallacy' (Furlong \& Cartmel, 2006: 5) to focus on individual responsibility and self-determination without taking into account the powerful impact of existing social structures.

The term 'youth' is a concept which has attracted increasing sociological interest since the 1980s in understanding the extended and fragmented period that young people may go through before attaining full 'adult' status (Chisholm, 1993; Coles, 1995). 'Youth' has become an additional stage between childhood and adulthood to exemplify this protracted transition (see, for example, Bynner et al., 1997) and offers a sociological bridge between the widening poles of childhood and adulthood in the Western world. Youth is, however, more than the 'liminal' phase described in the rites of passage literature. As James and Prout (1997) suggest, growing up nowadays involves several transitional processes rather than a one-off initiation process: youth transitions extend 'over considerable periods of time rather than being concentrated 
into ritual moments' (ibid: 248). Roberts (2003: 6) goes further in suggesting that: 'Most sociologists have abandoned trying to define youth in terms of chronological age. Nowadays we say that we study youth transitions which may occur at age 12, 16, 20,30 or even when individuals are older than this'. He goes on to argue that 'Some people never establish themselves in jobs which will support an adult lifestyle. Some remain unmarried and childless, and continue to live in their parents' homes until the latter's death' (ibid: 8).

Nevertheless, it is in the late teens and twenties that many people experience discrimination, socially, legally and economically, as a direct result of their age, and hence their status as being in limbo. Transitions research seems to have become preoccupied with the structure/agency dichotomy within an extended and increasingly adverse socio-economic environment and this preoccupation seems to be at the expense of the notion of citizenship, reciprocity and rights. The political and social power imbalances operating within our society, and the macro-level issues of young people's rights within a developmental framework of transitions, tend to be played down in favour of identifying localised structural constraints and individual choice. Indeed, Callinicos (1999) suggests that Giddens' theory of structuration ${ }^{1}$, for example, supports New Labour's Third Way programme which stresses duties rather than rights, tokenistic social inclusion rather than social equality and individualised risk rather than collective responsibility.

\footnotetext{
${ }^{1}$ Giddens (1984) suggests that structures (rules and resources) are not only constraining but also enabling, albeit within limitations. Social actions tend to be routinised within the confines of structure but also reflexive.
} 
If, as Beck (1992) suggests, agency has superseded structure in youth transitions through the 'individualization' of young people, then it would seem reasonable to assume that the timing of such transitions would vary greatly between individuals, depending on their capacity to progress their life projects. However, there tends to be continuity in the overall timing of transitions, not least as reflected by the age-crime curve $^{2}$, where offending could be seen to increase and decrease over time in line with fluctuations in power and social status for young people. This general continuity between age and the transition to adulthood suggests that structural factors are more constraining than individual factors are enabling.

\section{OFFENDING IN TRANSITION}

The following section explores the three phases of transition (childhood, youth and adulthood) alongside the three phases of offending, namely onset, maintenance ${ }^{3}$ and desistance. It is argued here that much of the criminological literature fails to adequately differentiate between the first two phases of onset and maintenance, and also fails to see offending as a process of change in the transition to adulthood and desistance. Seeing onset and desistance as two discrete topics of enquiry is perhaps unhelpful in understanding offending and desistance in parallel. If one can find a common denominator between the two phenomena, one can perhaps better understand offending as a process of change for the individual. As criminological theory

\footnotetext{
${ }^{2}$ Blumstein et al. (1988) suggest that there is a strong and invariant correlation between the level of crime and age, namely that the level of offending curve starts in the early teens, reaches a peak in the mid- to late-teens and then declines rapidly thereafter. This has been referred to by Farrington (1994: 521) as the 'age-crime curve'.

${ }^{3}$ I choose to use the word 'maintenance' rather than 'persistence', since the latter often suggests not only dogged obstinacy or purposefulness, but also increased frequency of offending. Maintenance, on the other hand, suggests the possibility of merely keeping going with offending, with or without purpose, and can denote a reduction as well as an increase in offending behaviour.
} 
currently stands, there seems to be a lack of congruence and continuity between those factors influencing onset and those influencing desistance. On the one hand, sociocultural determinants tend to be seen as most influential in young people's propensity to start offending, and, on the other hand, individual determinants tend to be seen as most influential in young people's desistance from offending. Whilst political correlates (if not causes) are associated with onset, regrettably no such political 'solutions' are offered in the desistance literature. This anomaly - that marginalisation is associated with onset but not with desistance - requires further attention. This article aims to explore whether the socio-cultural determinants associated with starting offending are indeed markedly different from the individual determinants associated with stopping offending or are, in effect, two sides of the same coin, the common denominator being 'power'.

Most theories in the criminological literature support the proposition that social integration, whether this be by individual, structural or political means, is an important factor influencing the behaviour and attitudes of young people in transition today. Most theorists agree that young people tend to be keen to adjust within society, to strive to achieve their aspirations and to be recognised by society as a whole for their efforts (see, for example, Roberts \& Sachdev, 1996; Wallace, 1987). Subcultural and other criminological theories on their own, whilst allowing a description and analysis of why young people may choose deviant means to conventional ends, do not take full cognisance of young people's expectations and aspirations as well as their lack of opportunities, rights and status during the transition to adulthood. 
Whilst research on youth transitions has been used relatively sparsely in the field of criminology ${ }^{4}$, it is argued that such literature can provide a better understanding of youth offending as perceived and experienced by young people. Not only are the phases of transition important markers to young people, but they should also be important markers to criminologists keen to understand the usually temporary and youthful nature of offending. Studying youth transitions in parallel with youth offending enables an exploration of the dynamics of age, power, interdependence and integration in the transition to full citizenship in adulthood. These twin processes of transition and offending are marked by a shift in the significance and influence of the family and the friendship group as children grow older and the importance of youth culture in the transition phase. It is argued in this article that the successful transition from the world of youth to that of adulthood is one of the culminating factors in reducing offending behaviour by young people.

\section{THE SCOTTISH DESISTANCE STUDY}

The study under discussion (Barry, 2006) explored the reasons for, and advantages and disadvantages of, starting, continuing and stopping offending amongst 40 current or previous persistent young offenders, 20 male and 20 female, aged 18-33. All of the men and seven of the women were approached via the auspices of a voluntary organisation running intensive probation projects in Scotland, and the remaining thirteen women were ex-probation clients referred to the researcher via various social work departments. All had been on probation in the past and the mean average number of previous convictions for the men was 24 and for the women 12 . The majority of interviews were conducted in respondents' own homes, although six were

\footnotetext{
${ }^{4}$ Although, see Bottoms et al. (2004), Harada (1995) and MacDonald and Marsh (2005).
} 
interviewed in prison and four in probation project offices. The interview, which lasted on average one and a half hours, involved in-depth discussion of offending histories, biographies, reasons given for onset, maintenance and desistance, the advantages and disadvantages of starting, continuing and stopping offending, and future expectations and aspirations.

\section{Starting offending}

Four-fifths of the respondents started offending under the age of 15 and the most common first offence was shoplifting. They suggested that they were primarily influenced by the fact that their peers were offending and that they were encouraged or chose to offend in order to be seen as part of that friendship group:

I was hanging about with a few pals that had money... if my friends can buy it, I can get it for nothing, just like that... I just wanted to be in there too... I didn't want to be the odd one out (21 year old male).

Two-thirds of the respondents - and most notably the women - cited the contact with and attention of friends or partners as key influences in their starting offending. Gilligan (1982) suggests that young women are more likely to be influenced by their need for attention from and interaction with other young people in the transition to adulthood, but the influence of male drug-using partners in particular was a key risk factor for these young women and this is explored further in the following section.

Most of these young people's sources of social supports in childhood came predominantly from friends rather than family not least where pre-empted by familial 
breakdown or instability, in which case school friends became a crucial social network. Whilst the literature on transitions and social capital suggest that families can be a crucial source of support for young people in childhood and youth (Holland et al, 2007; Allatt, 1993), young people from disadvantaged backgrounds with a history of family breakdown and abuse are more likely to seek such social capital from friends rather than family, even though this may result in them starting offending. The kudos gained from offending was often perceived not only as an attractive and available means of self- and social-identity but also was often the only means of making friends, as the following quotation illustrates:

I was looking for, I suppose in a way, folk to look at me in a different light. For folk to think of me differently - to fit in, in a way... and to be noticed by my mother and stuff, you know, with her alcohol abuse, I was always like alone and it was very difficult to like, I don't know, to get on with anyone, you know... I was picked on at school. I tried to keep myself to myself and other folk don't like that and I was an outsider so they went out of their way to do you know, and that was what the main problem was really... I had to make friends because I was alone in a strange countryside village with no one that I knew about me and it was like, how - what can I do? Where am I gonna turn, you know? And to me, [offending] was my only escape' (19 year old male).

Indeed, the majority of respondents suggested that the family was not a source of support for them, and that they often turned to friends for sociability and self- and social-identity. To them, the kudos gained from offending boosted their reputations and status. Many suggested that in childhood they were proud of their reputations as offenders, since it gave them much needed attention within their peer group. If 
successful, offending was also a valued source of 'pocket money'. However, the money they gained was generally - at this early phase of offending - only useful in relation to social rather than personal gain: they could acquire items which brought social acceptance and status amongst their peers - such as designer clothes, alcohol, drugs, cigarettes and make-up, all of which were seen as symbols of getting older and becoming adult. The economic gain of successful offending thus gave them increased status and reputation with their peers. The expression 'buying one's friends' further epitomises the duality of these economic and social aspects.

In terms of gender differences in starting offending, the women tended to cite social reasons (for attention or friendships) as the main influence in their starting offending, whereas the men tended to cite practical or personal factors. Whilst both men and women saw the financial benefits accruing from starting offending, the women were more likely to want such money for drugs, whereas the men would be more likely to spend it on consumables. This finding runs counter to a study undertaken by Miles et al (1998) which suggested that young women placed greater emphasis on consumer goods than young men, in terms of gaining confidence and status from feeling and looking stylish. Equally, this finding runs counter to Pudney's (2002) study where young men are generally more likely to be at risk from drug use than young women and therefore need to offend in order to purchase drugs. This anomaly in the present study may have resulted from the fact that some of the women in this sample were older than the men, had already experienced drug use and were more likely to start offending out of necessity to gain money for drugs rather than for consumables per se. 
The men were perhaps young enough not to be dependent on, or lured by, drugs at that early stage in their offending histories ${ }^{5}$.

The women were also more likely to cite the latent adverse effects of traumatic childhoods, such as sexual abuse or family illness or bereavement, as major factors in their starting offending, which may in turn have exacerbated their drug use:

'When I was younger I got interfered with. That's got a lot to do with it, with anger and that... I was only four' (20 year old female).

It was a horrible childhood... my mum and dad split up when I was $14-$ happiest day of my life when my mum and dad split up because she was just a punch bag to him (33 year old female).

The women were more than twice as likely as the men to see the advantages of starting offending. Indeed, their calculation of the monetary gain in starting offending makes the fact that they eventually stop offending all the more incongruent, given that they seemingly stopped more easily than the men. Likewise, given that the men could see few advantages in starting offending, it is perhaps surprising that they carried on with such activity for so long. When asked what they perceived as the disadvantages of starting to offend, the women were twice as likely as the men to cite factors such as being embroiled in the criminal justice system (e.g., getting caught, having court appearances and being detained) and losing the trust of their family and local community. As will be seen in the following section, however, the balance of

\footnotetext{
${ }^{5}$ Nevertheless, this sample of men did not apparently develop the kind of problem drug use experienced by the women, with only one young man mentioning being placed on a methadone prescription as a result of addiction compared with eight young women.
} 
advantages to disadvantages changes dramatically between the sexes as these young people moved through the phase of starting to that of maintaining offending.

\section{Maintaining offending}

The criminological literature on offending, as suggested earlier, tends not to differentiate between what I call the two phases of 'onset' and 'maintenance' of offending, and yet there are important differences in the risks and benefits of offending over time, as will be illustrated below. At the time of interview, over half the respondents had been involved in offending for between 6 and 9 years, although the majority had since stopped offending. Ten of the 20 men and 18 of the 20 women stated at interview that they had stopped offending, although the official reconviction data collated two years after interview suggested that eight of the men and five of the women were still accruing convictions. Whilst the type of offence committed varied minimally between onset and maintenance, the frequency and sophistication of that behaviour increased over time, as did the reasons and justifications for that behaviour. For example, whilst most offending initially was for sociability reasons or for money for consumables, it increasingly became a solitary activity and a means of funding only a drug habit, especially for the women. The longer they offended, necessity overtook sociability and routine replaced excitement. Offending often became a business, with customers replacing friends as the raison d'etre:

I thought this was getting better and better, so what's the point in stopping...

You can make quite a lot of money from [shoplifting]. Well I did anyway...

What I can make in five minutes, people couldn't make that in a month... I 
know I'm good at it. A lot of people have told us. The police and that have told us (23 year old male).

As my face got known for shoplifting, I stopped that and went into house breaking... I went on to fraud, credit card fraud... I was making about $£ 300$ to $£ 400$ a day and it was just going on purely drugs... I was a prostitute and using credit cards to go buy clothes to work in ( 27 year old female).

However, for the ten men and two women who said they were still offending at the time of interview, the main reason given was because it had become a habit, irrespective of any utilitarian gain: 'It's just inside us and I can't get out of it... I'm used to doing it' (23 year old male). One man suggested that offending was now a way of life that he couldn't control: '... it's now a habit, like an addiction'. Equally, some came to expect, even depend on, a certain level of income: '[I'm] used to having things... Used to having everything... The money and everything that comes with it' (23 year old female). It could be argued that this 'force of habit' has wider connotations, in that the status quo may be more secure and preferable to a change in lifestyle or peer group. The need to uphold a reputation could also be seen as wanting to maintain the status quo amongst existing friends as a 'facesaving' mechanism, rather than giving up what is known for something that is uncertain: 'I think it was because nobody knew me... I felt as if I had to make a name for myself' (24 year old male). Bromley (1993: 11) highlights this need to maintain a reputation gained in the past because to do otherwise would draw adverse attention to their seemingly changed persona: 'The autonomy of reputation, as a process distinct from the personality it is supposed to reflect, is the cause of much ambivalence'. Nevertheless, although this suggests a greater focus 
on agency than on structure, there is no doubt that the status quo may be the only option for many of the sample. Because of their reputation as an offender and because of limited legitimate income, they are likely to have less opportunities to adopt a more conventional lifestyle or gain legitimate income through employment.

Money for drugs became increasingly important to many of these young people in the maintenance phase, with many adapting their offending to maximise the economic gains anticipated. Whilst consumption of clothes, leisure, cigarettes and alcohol were important to these young people in youth, many of the sample - most notably the women - required money to maintain a developing drug addiction. The young women were more likely to speak of relationships with partners who were also offending for drugs, and this created a dichotomy for many of the women who wanted to support their partner's lifestyle, but did not necessarily want to match their partner's drug habit. Often when a relationship had started out as a source of love and attention, it rapidly became a liability, often resulting in domestic violence and addiction as well as stigmatisation within these women's wider social networks.

Covington (1985) and Taylor (1993) suggest that drug-related offending by women is often partner-induced, initially to please the partner but often latterly because of coercion through abuse or the women becoming addicted to drugs themselves. For the majority of the young people in this sample (16/20 men and 18/20 women), drug or alcohol use was seen as the main reason for, or an influence in, their offending in the past. Of those who saw substance misuse as the main reason for their offending, the majority cited drugs rather than alcohol as the precipitating factor: 'I think drugs were probably my downfall' (20 year old male); 'When I was like on the amphetamines 
and then coming down, I felt like I could get away with it... I did feel as if I could get away with a lot' (27 year old female). Early offending, both in terms of experimenting with drugs or committing other offences such as theft, tended to be for fun or for friendship for these respondents. However, for the young people in this sample who started taking drugs or alcohol on a more sustained basis, 29 (11 young men and 18 young women) considered that their use of these substances was problematic at some point in their lives and had increased their propensity to offend over time. There was then a noticeable shift in the reasons for offending if the individual became addicted to a substance and needed money to fund their usage: 'I was getting addicted to speed. When I was 16 years old, I was on an ounce a day, which is $£ 80$ so I had to steal to get my habit' (23 year old female):

I didn't realise it was killing me. I didn't think there was anything wrong with me but it got to a point every day you wake up, you do the same thing, you get up, you've the clothes on you had on from the night before, you get up, you find where you're going to get money from, you'd walk for miles and miles, you'd climb a mountain for a tenner at the top of it and you'd walk back down it again and buy yourself a bag [of heroin]. You wouldn't eat. The only thing you would eat was chocolate. If you never had money for chocolate... you'd steal a bar of chocolate to keep your sugar level up (21 year old female).

The above findings suggest that the men and women diverged in their 'choice' of whether to offend or not in the maintenance phase. The men were more likely to be dependent on the status gained from offending whereas the women were more likely to be dependent on drugs as a result of starting to offend, and therefore chose to commit specific offences in the maintenance phase to fund their habit. Substance 
misuse and crime have tended to show a close association that cannot be put down to chance alone. Whilst crime rates have dropped since the early 1990s in most Western countries (Leonardsen, 2003), there have been 'alarming trends' in increased substance misuse since the Second World War (Pudney, 2002). Whilst Rutter et al. (1998) and Pudney (2002) suggest there is uncertainty as to whether drug and alcohol use predispose individual users to crime or vice versa, the above statistics nevertheless suggest a negative association.

Just as many of the young women in this sample suggested that a methadone programme to stabilise their drug use would have precluded any need to offend, likewise many suggested that offending would not have been so necessary if they had found employment. However, legitimate employment was elusive to the majority of them, who seldom had the skills, qualifications or social networks necessary to find paid work. With such structural constraints in the transition between school and eventual employment, offending was one way of ensuring some form of income, however precarious such activity was. Equally, whilst offending may have initially been seen a source of kudos and status for these young people, as their offending became more persistent, their reputations were undermined greatly by their involvement in the criminal justice system, thus further undermining their chances of finding employment. The disadvantages of offending eventually outweighed the advantages at a time when wider social networks and responsibilities (to themselves and their families) became increasingly valuable to them. They seemed no longer to value the advantages of offending accrued in the childhood and early youth phases but wanted to progress to adulthood and more conventional opportunities and responsibilities. 
When comparing reasons and advantages or disadvantages of starting with those of maintaining offending, the data support the suggestion made earlier that these are distinct phases of offending which cannot be justifiably combined in an understanding of youth offending over time. What had started out as generally sociable and enjoyable criminal activity in the onset phase had become isolating, habitual and increasingly risky behaviour for many in the maintenance phase. The public image of being a successful offender, however, was important to the men in particular in the early stages of the maintenance phase, even though such a reputation may have caused them ambivalence more latterly (Bromley, 1993). Although people cannot be seen as responsible for the reputations others attribute to them, they are nevertheless held to account for that reputation being either sustained or abandoned. In addition, in a community where young people - especially young men - have few alternative sources of power or friendship, maintaining a public image, however difficult to uphold, serves an immediate and pragmatic purpose. However, to uphold and build on one's reputation as an offender in the transition to adulthood often required these young people to focus in on that offending activity and to view their offending more as a business or way of life. They internalised the social identity that they had developed over time.

The reasons given for continuing offending were rarely synonymous with the reasons for starting offending, and it seems that the initial kudos, sociability or excitement gained from offending soon wore off as drug use increased, practical need took over or 'criminal justice system fatigue' set in. Their offending seemed to become very much a pragmatic means of sustaining a certain lifestyle or habit in the seeming absence of an alternative lifestyle, and few were currently satisfied with their 
situation. Thus, many of the respondents talked of distancing themselves from offending peers in the latter stages of the maintenance phase, suggesting the beginning of the process of desistance.

\section{Stopping offending}

Ten of the men and 18 of the women suggested they had stopped offending at the time of interview and the majority of these young people also suggested they had done so within a year prior to interview. This was broadly supported by the official data collated two years after interview, suggesting that the vast majority had maintained an offence-free lifestyle since their decision to stop. Reasons for stopping offending revolved around the risks of being incarcerated and of losing people close to them. Both these risks were more acutely felt by the young women who often had children whom they felt increasingly responsible for and whose welfare was linked to the mother being both in the community and free of a drug addiction. Not only losing a child through the mother's death but also losing the child to the care of the social work department were both concerns voiced by some of these young women.

The 'hassle factor' which accompanied offending (e.g., getting caught, getting tired and disillusioned or having a criminal record or reputation) was also a major factor in their reasons for stopping:

I'd just had enough... I had enough of going around and getting lifted by the police and that. Everything what was happening, I was getting blamed for, even when I was in the jail they were coming [to my house] saying that I had been 
seen, they said 'we saw your son walking down the street with a telly'. I was in the jail! (22 year old male).

I had just grown up, realised the serious trouble I had been in... and well, at 20, I had my own house at this point... At the start, I had all nice stuff in it and then like with the heroin, I had sold it all for $£ 20$ at a time. Everything, and then I just thought to myself 'what am I doing here? I've got nothing. I'm in my twenties'. Do you know what I mean?... and I was 'right, that's enough, time to grow up here'... the police knew... it was this house I was dealing in, right, and they were sitting right outside... the door was going constantly... that was enough. That was enough after that (23 year old female).

The advantages of no longer offending were mainly to do with no longer being the focus of police attention and no longer fear imprisonment: Well you're not curtain twitching, you're not looking over your shoulder. Look at the grey hair I've got and I'm only 28 . Gee whizz, man!' (28 year old male); 'Not having to worry about anything, about the police coming to the door. Nobody can come to me now and say 'you've done this' because I've not done nothing' (27 year old female).

Those close to these young people seemed to become increasingly important as they moved into early adulthood. Social networks were also more influential for the young women in the sample (11/18 women compared with $5 / 10$ men), for example, because of now having responsibility for children, because of the positive impact of a relationship or because of the support from family more generally: 
Reasons for stopping? Well the kids, know what I mean. To try and make a family... I just didn't want to hurt them anymore. I knew I had hurt them enough. [My daughter] had seen so much... She hadn't seen the needle or nothing, know what I mean, but kids aren't stupid (27 year old female).

... having a son. Once he was born, then I really put the foot down... Because I had someone else I had to look out for other than myself... my son, he was too young to look after himself. That's my job (24 year old male).

The women suggested that they were more determined to stop offending if such offending meant jeopardising a loving relationship with a non-offending partner. They were also nearly three times as likely as the men to mention having freedom, control, pride and a 'normal' life again and were twice as likely to mention having improved relationships with family, children and partners. One's improved reputation was equally important to both men and women, with respect and 'honest money' being advantages of no longer offending: 'You get respect... I feel proud because you're not committing offences. You're not letting people down' (18 year old male); ' People don't look down their noses at you anymore cos they don't see you as a hooligan. It sort of gives you a bit sort of respect' (24 year old male).

I don't feel like scum anymore... [I] feel worth something now. I can make something of myself now. Get on with my life. I want to have babies and I want to get married. I just want all the normal things in life and I feel now that I'm grown up a wee bit and my head's more clearer. I've got a lot of loss of memory with drugs and I've still got a lot of very bad depressions but I've sort 
of got my family back a wee bit. I don't want to ever lose that, it's so sad (23 year old female).

The increasing pragmatism and disenchantment in the desistance phase was closely related to the 'hassle factor' mentioned above, but was also associated with a developing realisation that offending was not compatible with their increased need and desire to achieve conventional goals. The vast majority of this sample had similar conventional aspirations to those of young people more generally, namely a job, a house of their own and a family of their own (Barnardo's, 1996; Barry, 2001). Thirteen men and 13 women mentioned wanting a job, and seven men and 10 women wanted a house of their own. Seven men and five women mentioned having a settled family life, but only after they had gained stable employment.

Employment is often cited in the desistance literature as being a major precursor or trigger to desisting and yet 24 of the 28 desisters (8/10 male and 16/18 female respondents) did not have employment but still considered that they had managed to stop offending. Of the five young people employed at the time of the interview (3 men and 2 women), one young man said that he was still offending. However, none of the employed desisters equated their desistance with actually finding employment, although one commented that a job helped in terms of giving him something to do during the day. Other comments included: 'I got the chance to prove I could work for money' (23 year old male); 'I can work for money now. I don't need to steal it' (23 year old male); and 'Well now I've got a job... Well I've got something to look forward to. I've got something to look forward to when I get up in the morning' (22 year old male). 


\section{DISCUSSION AND CONCLUSIONS}

These findings suggest that young people may start offending as a means, however misguided or short-sighted, of social integration, whether this be through the acquisition of consumables or of 'friends'. Offending offered possible status and identity in moving from the confines of the family in childhood to the wider social network of the school milieu. However, in the maintenance phase, sociability and status were overtaken by necessity, resignation and addiction. Although they may not have had a lot to lose materially in the youth phase, the 'hassle factor' of the criminal justice system became increasingly inhibiting and relationships with family, partners and children became stronger and more empathic. Thus, the two key factors associated with desistance for these young people tended to be practical or social: that is, criminal justice system 'fatigue' or because of relationships with, or the support of, family, friends and significant others. Opportunities for 'conventional' living (through employment, or renewing and developing family relationships, for example) tended to result in a reduction of offending behaviour in adulthood for several reasons. The impetus to desist from offending could be gained through opportunities to take on responsibilities, or to break with past associates in favour of law-abiding partners, thus making offending less attractive. There tended to be a renewed emphasis on the need for family for support and a greater empathy with one's parents. State benefits also became an alternative source of income for those aged over 18 and those prescribed methadone found the economic savings considerable. Relative stability in young adulthood, through either employment, the status accruing from having responsibilities for oneself or others, or having one's own family or tenancy were all important status symbols to young people hitherto in limbo. 
Whilst these findings generally support the theoretical evidence on desistance, there are certain anomalies. For example, the majority of the sample managed to stop offending even though they were neither in a stable relationship nor in employment. Many reasons given for stopping offending were reactive or resulting from adverse experiences rather than proactive or resulting from encouragement or practical opportunities. The majority of these respondents suggested that they made an active decision to stop offending because of the previous loss of control in their lives resulting from the structural constraints placed on them by their reputation and lifestyle, and arguably by their age and status as 'young people' in transition. Whilst they may have drifted into offending in childhood, their agency and determination to leave such a lifestyle in early adulthood was particularly strong, given that this decision meant giving up something that they were accustomed to, successful in or addicted to. There were few, if any, 'pull' factors involved, and this made their resolve all the more powerful.

Social networks of family and friends are a crucial source of support for young people in transition. Nevertheless, the period of youth is one where boundaries are blurred, guidance and support are often reduced or passing from one source (the family) to another (the friendship group), and where responsibilities are not wholly acknowledged as legitimate or sustainable. This phase in the transition to adulthood is the one in which most offending takes place. Youth is the phase when young people have few socially recognised means of legitimating their stake in the social world but may see offending or its benefits as their only means of gaining recognition meantime, even if such recognition comes only from the temporary network of friends within the school and wider local community. 
It is argued that combining criminological and transitions theory enables linkages and consistencies to be identified between the three phases of starting, maintaining and stopping offending and the three phases of youth transitions. Whilst theories of youth transitions cannot explain offending behaviour per se, they can help understand the unequal distribution of power for young people in transition, which offending may help to rectify in the short term. Likewise, youth transitions exemplify the structural constraints which young people have to contend with because of their age and status. It could be argued, however, that those structural constraints are socially constructed and sustained by an adult world which discriminates against youth. It has been shown throughout this article how important other people are to young people in transition, and in particular how important it is for them to gain the respect and trust of adults in that transition. One young women from this research voiced her hopes for the future thus: 'Put faith in me. Give me another chance. Trust me'. Without such reciprocal arrangements in youth, offending is likely to become entrenched and young people are more likely to become yet further disillusioned and disempowered in the transition to a potentially uncertain and unstable form of adulthood. 


\section{REFERENCES}

Allat, P. (1993) 'Becoming Privileged: The role of family processes' in I. Bates and G. Riseborough (eds), Youth and Inequality, Buckingham: Open University Press.

Archard, D. (1993) Children: Rights and Childhood, London: Routledge.

Barnardo's (1996) Young People's Social Attitudes: Having their say - the views of 1219 year olds, Ilford, Barnardo's.

Barry, M. (2006) Youth Offending in Transition: The search for social recognition, Abingdon: Routledge.

Barry, M. (2005) 'Introduction’ in M. Barry (Ed) Youth Policy and Social Inclusion: Critical debates with young people, London: Routledge.

Barry, M. (2001) A Sense of Purpose: Care leavers' views and experiences of growing up, London: Save the Children/Joseph Rowntree Foundation.

Beck, U. (1992) Risk Society: Towards a New Modernity, London: Sage.

Blumstein, A., Cohen, J and Farrington, D.P. (1988) 'Criminal Career Research: Its Value for Criminology', Criminology, Vol. 26, No. 1: 1-35. 
Bottoms, A., Shapland, J., Costello, A., Holmes, D. and Muir, G. (2004) 'Towards

Desistance: Theoretical Underpinnings for an Empirical Study', The Howard Journal, Vol. 43, 4: 368-389.

Bromley, D. (1993) Reputation, Image and Impression Management, Chichester: Wiley.

Brown, S. (1998) Understanding youth and crime: Listening to youth?, Buckingham: Open University Press.

Bynner, J., Chisholm, L. and Furlong, A. (eds) (1997) Youth, Citizenship and Social Change in a European Context, Aldershot: Ashgate.

Callinicos, A. (1999) 'Social Theory Put to the Test of Politics: Pierre Bourdieu and Anthony Giddens', New Left Review, 236, 77-102.

Chisholm, L. (1993) 'Youth transitions in Britain on the threshold of a 'New Europe', Journal of Education Policy, Vol. 8, No. 1: 29-41.

Coles, B. (1995) Youth and Social Policy: Youth Citizenship and Young Careers, London, UCL Press.

Cote, J. (2002) 'The Role of Identity Capital in the Transition to Adulthood: The Individualization Thesis Examined', Journal of Youth Studies, Vol. 5, No. 2: 117-134. 
Covington, J. (1985) 'Gender Differences in Criminality Among Heroin Users', Journal of Research in Crime and Delinquency, 22 (4): 329-54.

Farrington, D. (1994) 'Human Development and Criminal Careers' in M. Maguire, R. Morgan and R. Reiner (eds) The Oxford Handbook of Criminology, Oxford: Oxford University Press.

Franklin, B. (Ed) (2002) The New Handbook of Children's Rights: Comparative Policy and Practice, London: Routledge.

Furlong, A. and Cartmel, F. (2006), $2^{\text {nd }}$ edition, Young People and Social Change: Individualization and Risk in Late Modernity, Milton Keynes: Open University Press.

Giddens, A. (1984) The Constitution of Society, Cambridge: Polity Press.

Gilligan, C. (1982) In a Different Voice: Psychological Theory and Women's Development, Cambridge, MA: Harvard University Press.

Harada, Y. (1995) 'Adjustment to school, life course transitions, and changes in delinquent behaviour in Japan', in Z.S. Blau \& J. Hagan (Eds), Current perspectives on aging and the life cycle: Delinquency and disrepute in the life course', pp. 36-60, Greenwich, CT: JAI. 
Holland, J., Reynolds, T. and Weller, S. (2007) 'Transitions, Networks and Communities: The Significance of Social Capital in the Lives of Children and Young People', Journal of Youth Studies, Vol. 10, No. 1: 97-116.

James, A. and Prout, A. (1997) 'Re-presenting childhood' in A. James and A. Prout (eds) Constructing and Reconstructing Childhood, London: Falmer Press.

Jones, G. (1996) Deferred Citizenship: A coherent policy of exclusion?, Young People Now, 26 March.

Leonardsen, D. (2003) 'The Moral Dimension in Crime - the Japanese experience', paper presented at the British Society of Criminology Conference, June.

MacDonald, R. (1997) 'Youth, social exclusion and the millennium' in R. MacDonald (Ed), Youth, the 'underclass' and social exclusion, London: Routledge.

MacDonald R. and Marsh, J. (2005) Disconnected Youth? Growing Up in Britain's Poor Neighbourhoods, Basingstoke: Palgrave Macmillan.

MacDonald, R., Mason, P., Shildrick, T., Webster, C. Johnston, L. and Ridley, L. (2001) 'Snakes and Ladders: In Defence of Studies of Youth Transition', Sociological Research Online, vol. 5, no. 4, http://www.socresonline.org.uk/5/4/macdonald.html.

Miles, S. (2000) Youth Lifestyles in a Changing World 2 Buckingham: Open University Press. 
Pudney, S. (2002) The road to ruin? Sequences of initiation into drug use and offending by young people in Britain, Home Office Research Study 253, London: Home Office.

Roberts, K. (2003) 'Problems and Priorities for the Sociology of Youth' in A. Bennett, M. Cieslik and S. Miles (eds) Researching Youth, Basingstoke: Palgrave Macmillan.

Roberts, H. and Sachdev, D. (1996) Young People's Social Attitudes: Having Their Say - The Views of 12-19 Year Olds, Ilford: Barnardo's.

Rutter, M., Giller, H. and Hagell, A. (1998) Antisocial Behaviour by Young People, Cambridge: Cambridge University Press.

Stephen, D. and Squires, P. (2003) “Adults don't realise how sheltered they are': A contribution to the debate on youth transitions from some voices on the margins', Journal of Youth Studies, Vol. 6, No. 2, June: 145-164.

Taylor, A. (1993) Women Drug Users: An Ethnography of a Female Injecting Community, Oxford: Clarendon Press.

Thomson, R., Holland, J., McGrellis, S., Bell, R., Henderson, S. and Sharpe, S. (2004) 'Inventing Adulthood: A biographical perspective on youth citizenship', Sociological Review, 52 (2): 218-293. 
Turner, V. (1967) The Forest of Symbols: Aspects of Ndombu ritual, Ithaca, NY: Cornell University Press.

Turner, V. (1969) The Ritual Process: Structure and Anti-Structure, Chicago: Aldine.

Wallace, C. (1987) For Richer, for Poorer: Growing Up In and Out of Work, London: Tavistock.

Williamson, H. (1997) 'Status Zer0 youth and the 'underclass': Some considerations' in R. MacDonald (Ed), Youth, the 'underclass' and social exclusion, London: Routledge.

Wyn, J. and White, R. (1997) Rethinking Youth, London: Sage. 